\title{
DIURNAL VARIATION OF PHYTOPLANKTON PRODUCTION AND SOLAR RADIATION IN COASTAL WATERS OFF CANANÉIA
}

(Received 8/12/60)

A. Garcia Occhipinti

A. Magliocca

Clóvis Teixeira *

C O N T E N T S

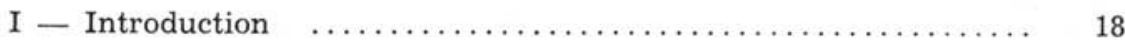

II — Equipment, methods and procedure $\ldots \ldots \ldots \ldots \ldots \ldots \ldots . \ldots 20$

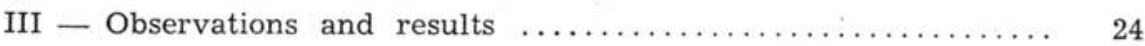

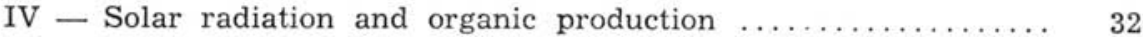

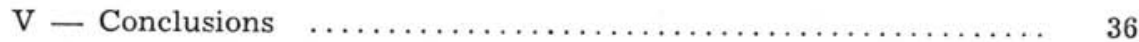

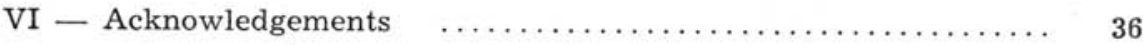

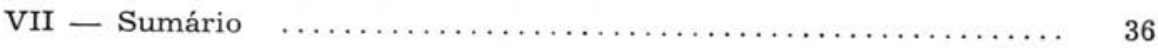

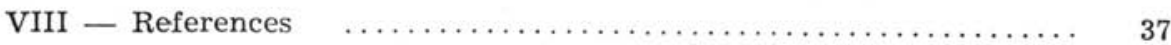

* Supported by a grant in aid of the National Research Council, Rio de Janeiro.

Publ. n. ${ }^{\circ} 150$ do Inst. Ocean. da USP. 


\section{I - INTRODUCTION}

\section{1 - General considerations}

The Instituto Oceanográfico da Universidade de São Paulo maintains in the region of Cananéia - southern coast of the São Paulo State - a Research Station (Fig. 1) where biological research, meteorological observations and physical and chemical data of adjacent sea waters have been regularly carried out during the past three years.

This region is also one of the frequently harvested areas of this part of the State of São Paulo coast (Richardson \& Moraes, 1960).

It is our purpose to contribute to the understanding of basic problems which are simultaneously being undertaken by other sections of this Institution and thus a series of investigations in the field of marine productivity was begun in an attempt to bring together several factors which are being observed and studied independently, establishing correlations between them, pointing out their mutual influences and trying to verify their periodical and spatial variations along this part of the coast.

The importance of this type of work was pointed out by Strickland (1955). This work is thus the first contribution to an appraisal of primary marine production in the Cananéia region.

Having studied the phytoplankton under a taxonomic point of view, its importance as a basic factor in the production of living matter in the ocean must be appraised. Productivity studies are therefore essential in marine biology, not only from the ecological point of view, but particularly as an appraisal of nutritive potential and energy reserve in terms of gross photosynthesis, plankton community respiration and phytoplankton standing crop.

\section{2 - WORKING PROCEDURE}

The first purpose of this work is to obtain preliminary data on the diurnal variation of the production of organic matter by natural populations in coastal waters as a function of environmental factors.

Many authors have shown that plant communities vary in their specific composition and react differently to the environment at different times of the day. In order to study such phenomena under 


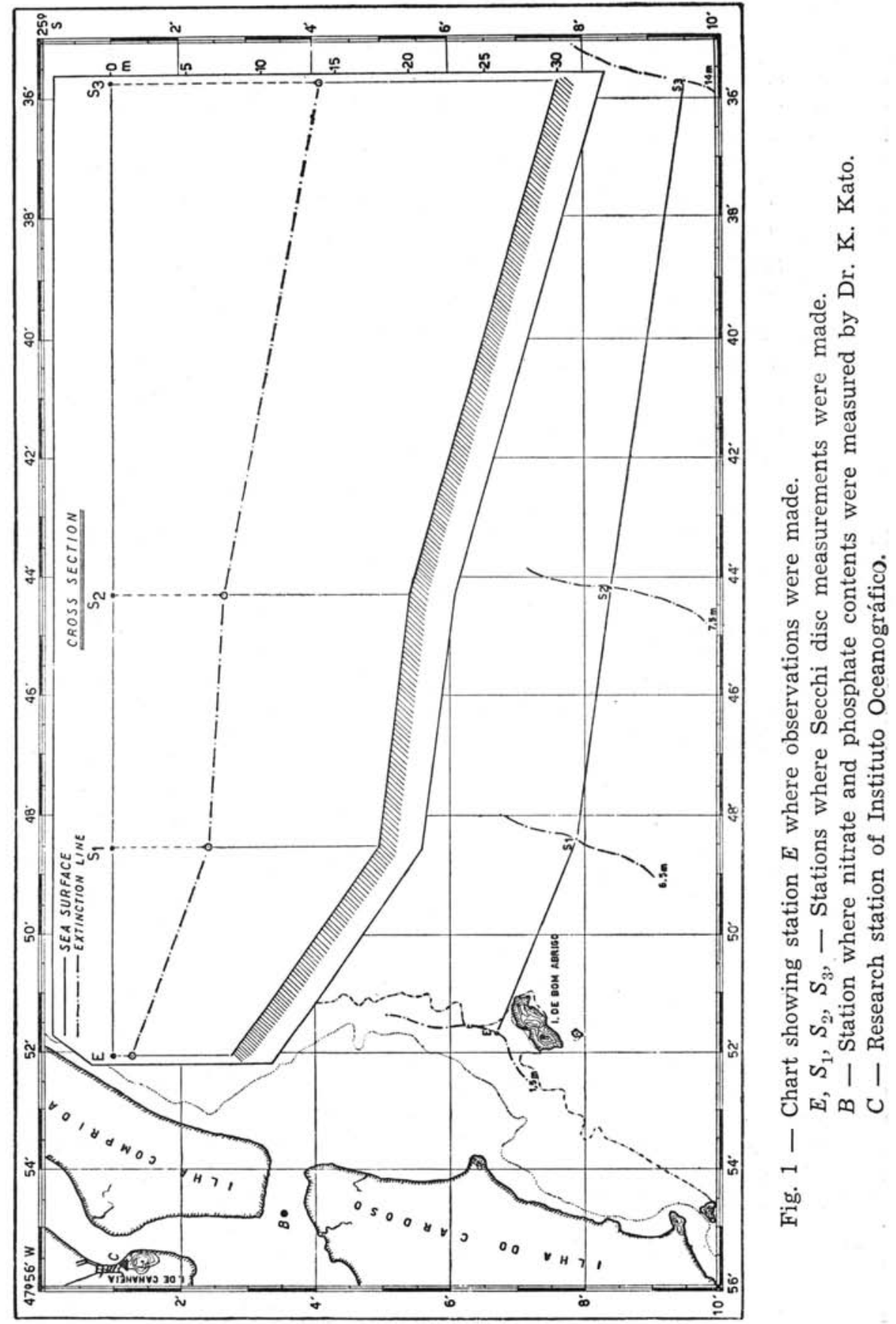


natural growing conditions it is obviously necessary to make observations at very frequent and short intervals. Therefore productivity measurements were made during the daylight period, every two hours, on two following days. The accuracy of the results was restricted to the methods employed.

The main factors considered in the primary production measurements were:

a) Marine organisms gross production rate.

b) Phytoplankton standing crop.

c) Chemical and physical environment.

d) Relationship between total incident energy and organic production.

\section{3 - Station}

Observations were carried out near Bom Abrigo Island, (Lat. $25^{\circ} 07^{\prime}$ S-Long. $47^{\circ} 51^{\prime} \mathrm{W}$ ), southern coast of São Paulo State - Brazil. In the chart (Fig. 1) the position of the station is shown at point $E$.

It must be noted that approximately at 4 miles $\mathrm{NE}$ from the chosen station lies the Cananéia outlet of the lagoon region of Cananéia which, owing to tidal currents effect, transports water of lower density from the lagoon region to the open sea. The latter water is easily recognizable by its brownish colour which is usually attributed to the abundant mangrove vegetation of the region.

\section{II - EQUIPMENT, METHODS AND PROCEDURES}

Physical, chemical and biological observations were made at two-hour intervals, two different levels-surface and at a depth of $2.0 \mathrm{~m}$, during two days, July 7 and 8, 1959. At midnight, July 7, one surface observation was made.

\section{1 - Organic production}

The organic production was determined by the oxygen technique, also called the "light-and-dark-bottle" method, introduced by Gaarden \& Gran (1927). Dissolved oxygen concentration was measured by Winkler's method. Water samples were collected both at surface and at $2.0 \mathrm{~m}$ depth by means of an insulating Petterson-Nansen water bottle. The samples were syphoned into "amber", "light" and "dark" bottles. "Amber" bottles were used to determine the "original" oxygen concentration before the beginning of each experiment; "light" and "dark" bottles were lowered to the same depths from which the samples came, suspended to a floating buoy for two hours exposure. 
The rate of respiration was determined including the respiration of both autotrophic and heterotrophic organisms, from the difference of oxygen concentration between "amber" and "dark" bottles and the rate of photosynthesis by the same difference between "light" and "dark" bottles. (Steemann Nielsen \& Hansen, 1959).

\section{2 - Chemical environment}

Water samples were collected at the same depths for the following analyses: a) pigments; b) inorganic phosphate; c) $\mathrm{pH}$ and chlorinity. The results are shown on Fig. 2.

a) Pigments - about $500 \mathrm{ml}$ of sea-water were used for pigment analyses. Two milliliters of $\mathrm{MgCO}_{3}$ saturated solution were added to the sample in order to avoid the decomposition of chlorophyll to pheophytin. The samples were then filtered by millipore-membrane filters and placed into test tubes which were wrapped in black paper envelopes before being stored in a masked vacuum dessicator, kept cool to minimize the enzimatic action. The pigment extraction was made by means of neutralized $90 \%$ acetone (the solubility of disturbing substances is depressed by the mixture with water) (Krey, 1958). Five milliliters of acetone were added to the test tubes which were left to rest overnight and then centrifugated.

The chlorophyll concentration was determined through a Beckman spectrophotometer model DU (Richards with Thompson, 1952; Creitz \& Richards, 1955; Davis, 1957) and calculated by means of Richards with Thompson equations. For chlorophyll $a$ the unit used was $\mathrm{mg} / \mathrm{m}^{3}$ and for carotenoids the Milli Specific Pigment Unit $/ \mathrm{m}^{3}$ (Richards with Thompson, 1952) which represents a close equivalent to one $\mathrm{mg} / \mathrm{m}^{3}$ of pigment.

b) Inorganic phosphate - The water samples were filtered, preserved with chloroform and kept in a dark and cold place (Murphy \& Riley, 1956) before being treated with molybdenium reagent and reduction solution. The inorganic phosphate concentration was determined through an Electrical Colorimeter Elko II - Zeiss.

c) $\mathrm{pH}$ was determined by means of a Metrohm pHmeter.

\section{3 - Physical environment}

a) The tide was measured by means of a tide rule and recorded hourly.

b) Water temperature was read on the thermometer of the insulating water bottle, at surface and $2.0 \mathrm{~m}$ depth and recorded every two hours during the daylight periods and once at midnight. 
c) Air temperature was recorded on a thermograph.

d) Extinction coefficient - A Secchi disc was used and the data were converted into extinction coefficients according to the Poole \& Atkins expression:

$0.025 I_{s}=I_{s} \times 10^{-K(2 D)}$ where $I_{s}$ is the energy per unit time and area that reaches the sea surface, $K$ (kappa) is the extinction coefficient per meter and $D$ is the Secchi disc reading in meters. The readings were taken every 2 hours during daytime.

e) Global radiation was obtained through a recording bi-metallic actinograph calibrated against a standard solarigraph.

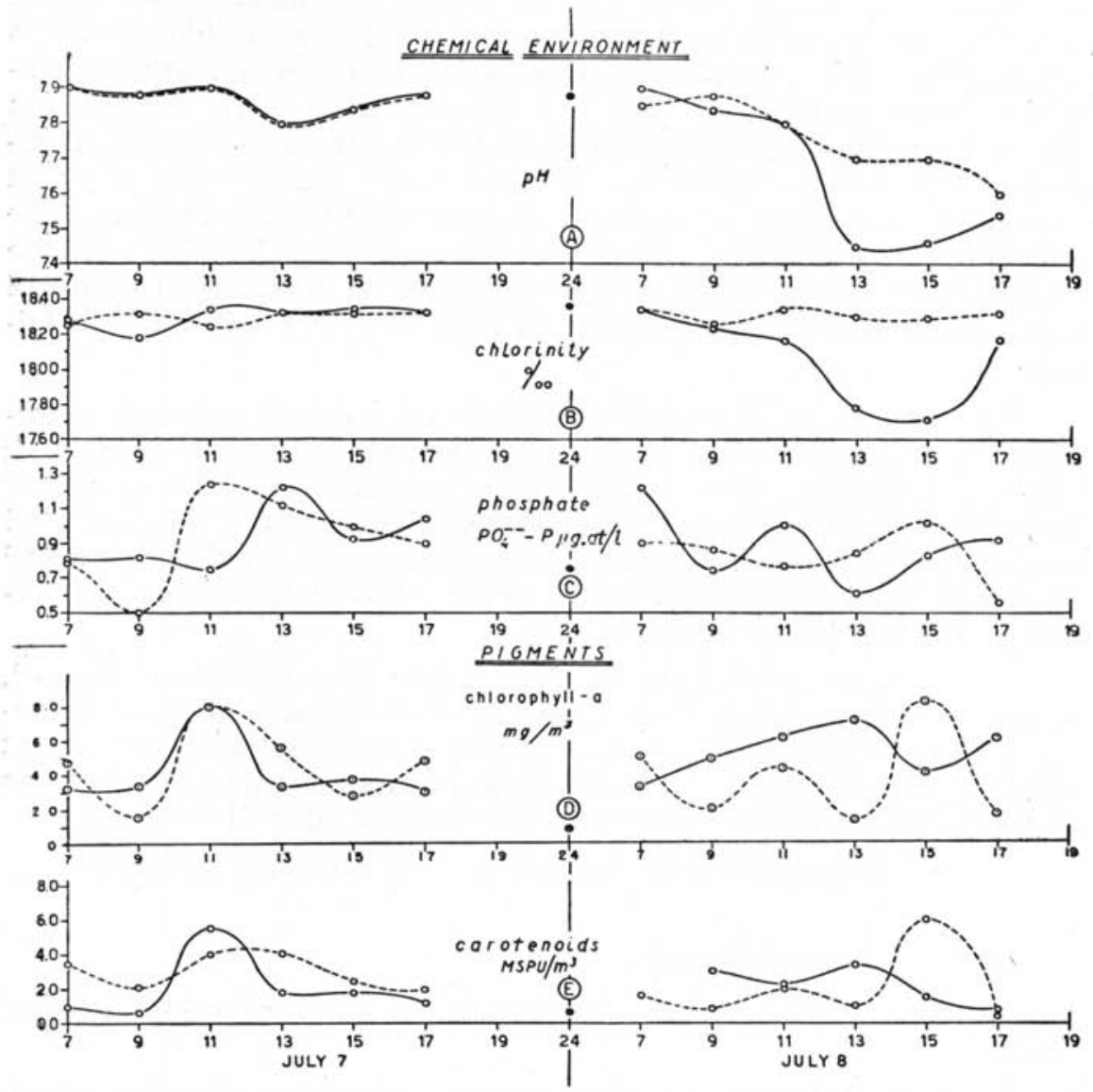

Fig. $2-$ Chemical variables measured between sunrise July 7 and sunset July 8, 1959. 


\section{4 - Biology}

a) Cell count - Numerical estimates of populations in organic production are essential to determine the correlations between the number of individuals and the production of phytoplankton. Although there are several methods used for these estimates none is entirely satisfactory when whole plant communities are considered as a whole, owing to the great variability in size and form of the phytoplankton elements (Braarud, 1958).

In spite of the long time required for its processing the filtration method was elected for the numerical determinations, because

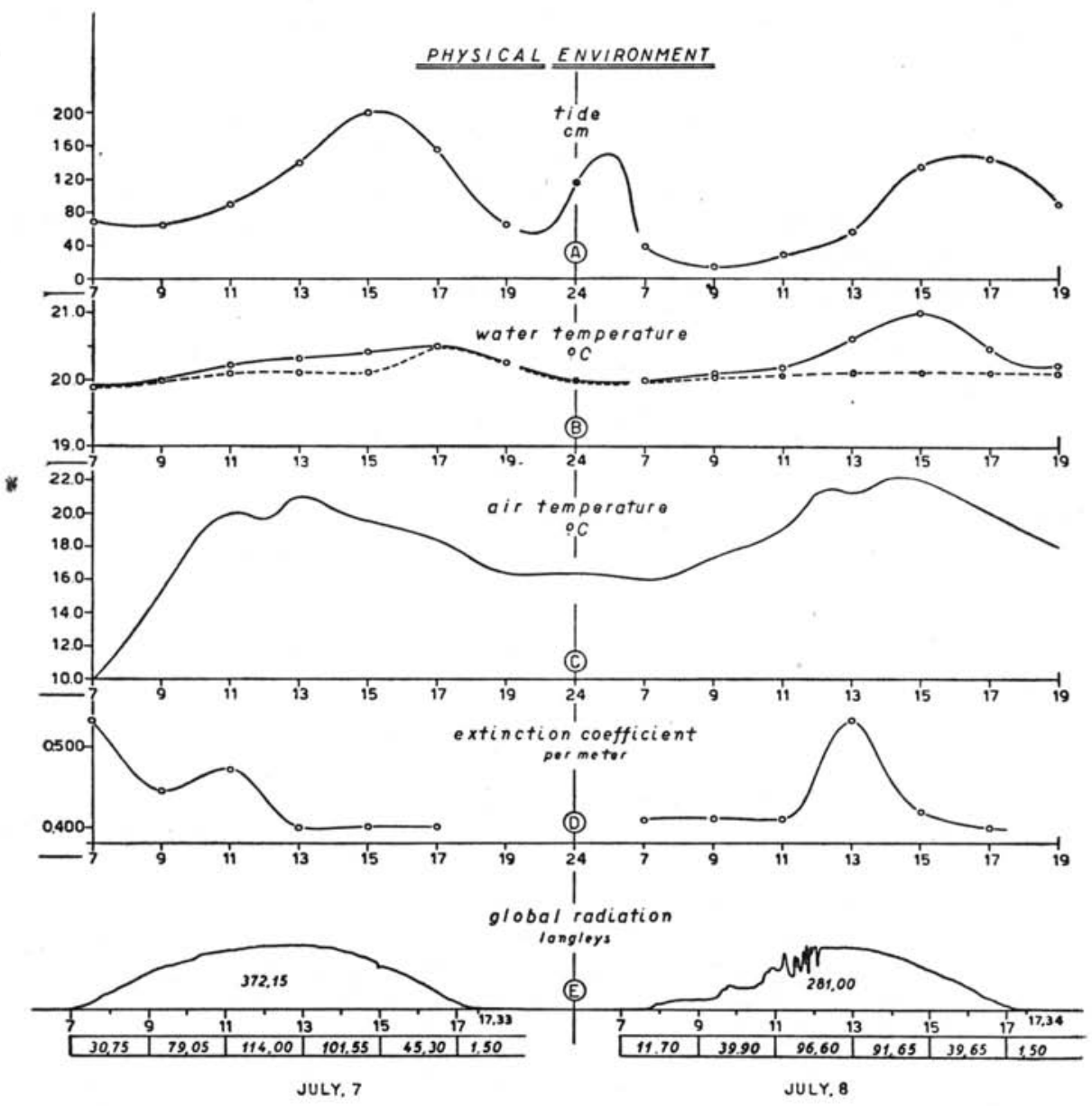

Fig. 3 - Physical variables measured between sunrise July 7 and sunset July 8, 1959 . 
it undoubtedly is one of the most efficient, since the filters retain even the smallest phytoplankton organisms.

Water samples of $300 \mathrm{ml}$ were collected and fixed by means of potassium iodide, iodine saturated, and filtered in millipore filters (AA). After the necessary filter treatment, the microscopical count was made according the "clump count method".

b) Taxonomy - Samples of the phytoplankton population were taken with a plankton net, and microscopic preparations made for the taxonomic determination of the predominant species.

c) Physiological state - A Sedgwich-Rafter counting cell was used for the observation of the physiological condition of the algae.

\section{III - OBSERVATIONS AND RESULTS}

\section{1 - DiURnAl production}

a) Main values - The experimental data permitted to estimate the value of gross production in plants, total respiration and net community production.

The diurnal variation of gross production rate are shown on Fig. 4.

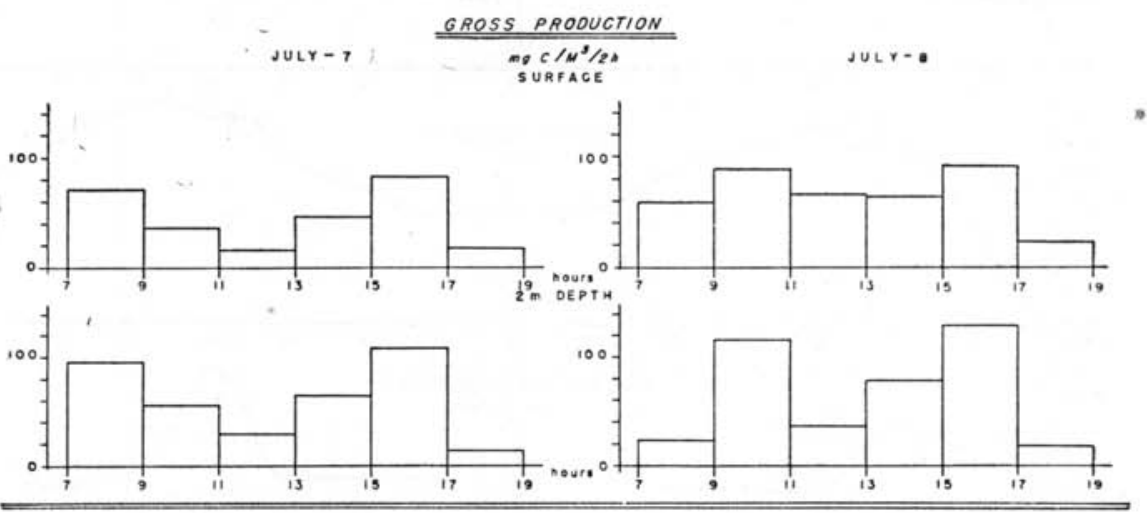

Fig. $4-$ Gross production at each interval of 2-hours exposure.

The values found for gross production were $0.271 \mathrm{~g} \mathrm{C} / \mathrm{m}^{3} / 12 \mathrm{~h}$ at the surface and $0.369 \mathrm{~g} \mathrm{C} / \mathrm{m}^{3} / 12 \mathrm{~h}$ at $2.0 \mathrm{~m}$ depth, on July 7 ; $0.399 \mathrm{~g} \mathrm{C} / \mathrm{m}^{3} / 12 \mathrm{~h}$ at the surface and $0.410 \mathrm{~g} \mathrm{C} / \mathrm{m}^{3} / 12 \mathrm{~h}$ at $2.0 \mathrm{~m}$ depth, on July 8. An assimilation coefficient was not taken into consideration. Fig. 5.

b) Net and gross production ratio - The ratios are shown on 
The values found were: 0.56 at the surface, 0.54 at $2.0 \mathrm{~m}$ depth on the 7th and 0.61 at the surface, 0.67 at $2.0 \mathrm{~m}$ depth on the 8 th.

The ratios are calculated for mean values of net and gross production during the diurnal period.

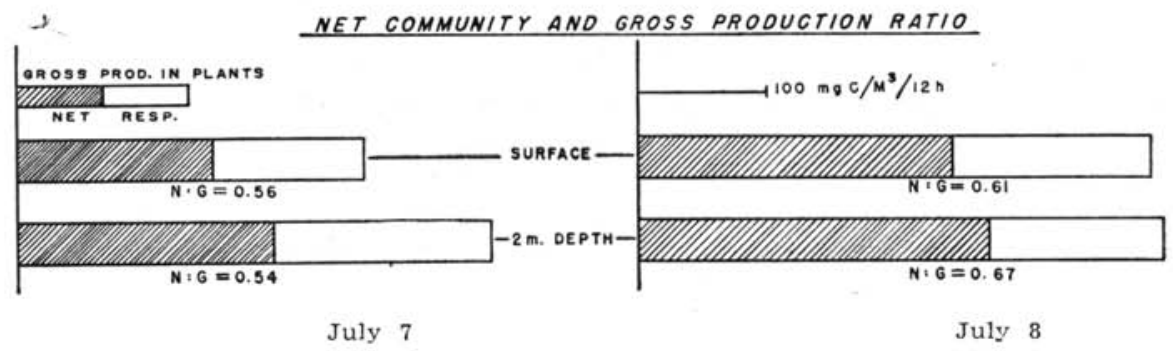

Fig. 5 - Comparison of mean values of net community and gross production for the daylight period.

On the 7 th, which was a cloudless day, the ratios were lower than those found on the 8 th, which was overcast during the morning.

These results might be attributed to the attenuation of the inhibitive effect of the high energy intensity on the overcast morning day, as well as to the higher standing-crop (chlorophyll and cell number and the population's physiological conditions).

\section{2 - Chemical environment}

a) Nutrients - The following values for the atomic ratio C:P:N: - 106:1:16 (plankton analyses), 105:1:15 (changes in sea-water) have been indicated by Sverdrup et al. (1946, p. 235-239), Redfield (1958, p. 205-222) and other authors.

The $\mathrm{P}: \mathrm{N}$ ratios are closely constant at about $1: 15$ atoms in sea water and in plankton organisms but it is evident that anomalous ratios are found, specially in some enclosed areas and in coastal waters.

In this work the $P: N$ ratios were assumed to be $1: 15$. A requirement of $34.0 \mu$ gat $\mathrm{C} / 1 / 12 \mathrm{~h}$ is necessary for a maximum photosynthetic rate of $0.410 \mathrm{~g} \mathrm{C} / \mathrm{m}^{2} / 12 \mathrm{~h}$, and $18.0 \mu$ gat $\mathrm{C} / 1 / 12 \mathrm{~h}$ for a minimum photosynthetic rate of $0.226 \mathrm{~g} \mathrm{C} / \mathrm{m}^{2} / 12 \mathrm{~h}$, in a one meter water column.

On these assumptions, a diurnal requirement of $0.32 \mu$ gat $/ 1$ of Phosphorus and $4.90 \mu$ gat/1 of Nitrogen for the maximum value of the gross production and $0.17 \mu$ gat/1 of Phosphorus and 2,80ugat/1 of Nitrogen for the minimum value of the gross production, were found.

The lowest value observed for inorganic phosphate was $0.50 \mu$ gat $/ 1$ while the maximum value required is $0.32 \mu$ gat $/ 1$. The values 
for nitrate measured in winter, by Kato (under press), indicate that they agree closely with the theoretical nitrogen requirement; however, these values cannot be accepted as conclusive, since they were not obtained at the same station at the same time (Table I). Kato's station is shown on Fig. 1, point $B$.

TABLE I

\begin{tabular}{|c|c|c|c|c|c|}
\hline $\begin{array}{c}\text { Depth } \\
\mathrm{m}\end{array}$ & $\begin{array}{l}\mathrm{PO}_{4}-\mathrm{P} \\
\mu \mathrm{gat} / 1\end{array}$ & $\begin{array}{l}\mathrm{NO}_{3}-\mathrm{N} \\
\mu \text { gat/1 }\end{array}$ & Station $(*)$ & Date & Author \\
\hline $\begin{array}{l}0.0 \\
2.0 \\
0.0 \\
2.0 \\
0.0 \\
2.0\end{array}$ & $\begin{array}{l}0.50 \\
0.70 \\
0.90 \\
1.06 \\
0.92(* *) \\
0.89(* *)\end{array}$ & $\begin{array}{r}<0.10 \\
<0.10 \\
4.20 \\
3.70 \\
- \\
-\end{array}$ & $\begin{array}{l}\mathrm{B} \\
\mathrm{B} \\
\mathrm{B} \\
\mathrm{B} \\
\mathrm{E} \\
\mathrm{E}\end{array}$ & $\begin{array}{c}\text { Summer-58 } \\
\text { Winter-58 } \\
\text { Winter-59 } \\
\text { W }\end{array}$ & $\begin{array}{c}\text { Dr. K., Kato } \\
", \\
\text { these authors } \\
\text { " }\end{array}$ \\
\hline
\end{tabular}

(*) See Fig. 1

(**) Mean values

On both days the inorganic phosphate variation at $2.0 \mathrm{~m}$ depth present a close relation to the organic production. The highest values of phosphate occurred at periods of greater incident energy and lower organic production rates. At the surface however, the tide influence altered this expected relationship.

b) Pigments - Chlorophyll $a$ concentration, Fig. 2, ranged from 1.3 to $8.2 \mathrm{mg} / \mathrm{m}^{3}$, while carotenoid pigment concentration ranged from 0.4 to $6.0 \mathrm{MSPU} / \mathrm{m}^{3}$ (Specified Pigment Units, Richards with Thompson, 1952). Chlorophyll $b$ concentration, showed lower values than chlorophyll $a$ concentration; on the other hand the chlorophyll $c$ concentration seldom showed values lower than chlorophyll $a$ concentration.

It was not possible to correlate the pigment concentrations with the cell numbers, since the water samples used for pigment determination were not the same used for cell counts.

It is interesting to observe that low organic production rates corresponded to high values of pigment concentration occurring during periods of high radiation intensity.

c) Chlorinity and $\mathrm{pH}$ - The chlorinity variation on the 7th was found to be 18.18 to $18.34 \%$ at the surface, while at $2.0 \mathrm{~m}$ depth the values showed a small variation keeping near to $18.30 \%$ (Fig. $2 \mathrm{~B}$ ).

The $\mathrm{pH}$ variation, at both levels, are comprised between 7.8 and 7.9 (Fig. $2 \mathrm{~A}$ ).

On the 8th, both chlorinity and $\mathrm{pH}$ showed great variations at the surface during flow and their curves have the same features 
(Fig. 2, 3), the chlorinity falling from $18.34 \%$ to $17.71 \%$ and $\mathrm{pH}$ from 7.90 to 7.40 . At $2.0 \mathrm{~m}$ depth, however, the chlorinity showed a small variation between 18.26 and $18.34 \%$. The lowest $\mathrm{pH}$ value was 7.60 .

The values, for both, were found to be slightly higher at $2.0 \mathrm{~m}$ depth than at the surface. Such variation may be attributed to tidal influence.

\section{3 - Physical environment}

a) Tides - During flow the denser oceanic waters move towards the lagunar system and sink under the lighter inshore waters, revolving the bottom and causing a counter-current at the surface which carries sediments and lower density waters, polluted and coloured, from the lagoon region to station $E^{\prime}$ where observations were done (Fig. 1).

The influence of these tidal currents is transitory and restricted to surface layers. The $\mathrm{pH}$ and chlorinity data (Fig. 2, $A$ and $B$ ), showed this fact very clearly on the 8th. The influence of these currents on other factors could not be observed. The range between high and low water mark, on both days, was approximately $1.40 \mathrm{~m}$.

b) Water temperature - The water temperature variations were small (Fig. $3 \mathrm{~B}$ ). The surface temperature varied from $19.9^{\circ} \mathrm{C}$ to $21.0^{\circ} \mathrm{C}$. At $2.0 \mathrm{~m}$ depth it varied from $19.9^{\circ} \mathrm{C}$ to $20.2^{\circ} \mathrm{C}$. These variations can be mainly attributed to the diurnal heating effect.

c) Air temperature - Showed a great amplitude during the first day, varying from $10^{\circ} \mathrm{C}$ to $21^{\circ} \mathrm{C}$, and a smaller one on the second day, from $16^{\circ} \mathrm{C}$ to $22^{\circ} \mathrm{C}$ (Fig. $3 \mathrm{C}$ ).

d) Water transparency - E'xtinction coefficient - Evaluation of water transparency was made by means of extinction coefficients calculated from Secchi disc measurements. The extinction coefficient varied from 0.400 to 0.532 at station $E$ (Fig. $3 \mathrm{D}$ ), according to these values this water may be classified as "turbid coastal" (Sverdrup, 1952). No ponderable effect on the extinction coefficient could be attributed to the sun's altitude variation. The water transparency increases with the distance from the coast and was observed along the line $E, S_{1}, S_{2}, S_{3}$, which is shown in cross section of Fig. 1.

e) Weather and sea conditions - July 7, 1959: Sky - Bright sunny day, with few Ci clouds. Wind - Light NW. Sea - Calm and smooth.

July 8, 1959: Sky - Overcast during the morning with a Sc cloud layer until noon; cloudless in the afternoon. Wind - Light NW. Sea - Calm and smooth. 
f) Global radiation - Main values - The daily global radiation, or total incident radiation (sun+sky) was obtained through the integration of the actinograph recorded curves (Fig. $3 \mathrm{E}$ ). The following values were found: - for the 7th: 372.15 ly.day- ${ }^{1}{ }^{(*)}$,

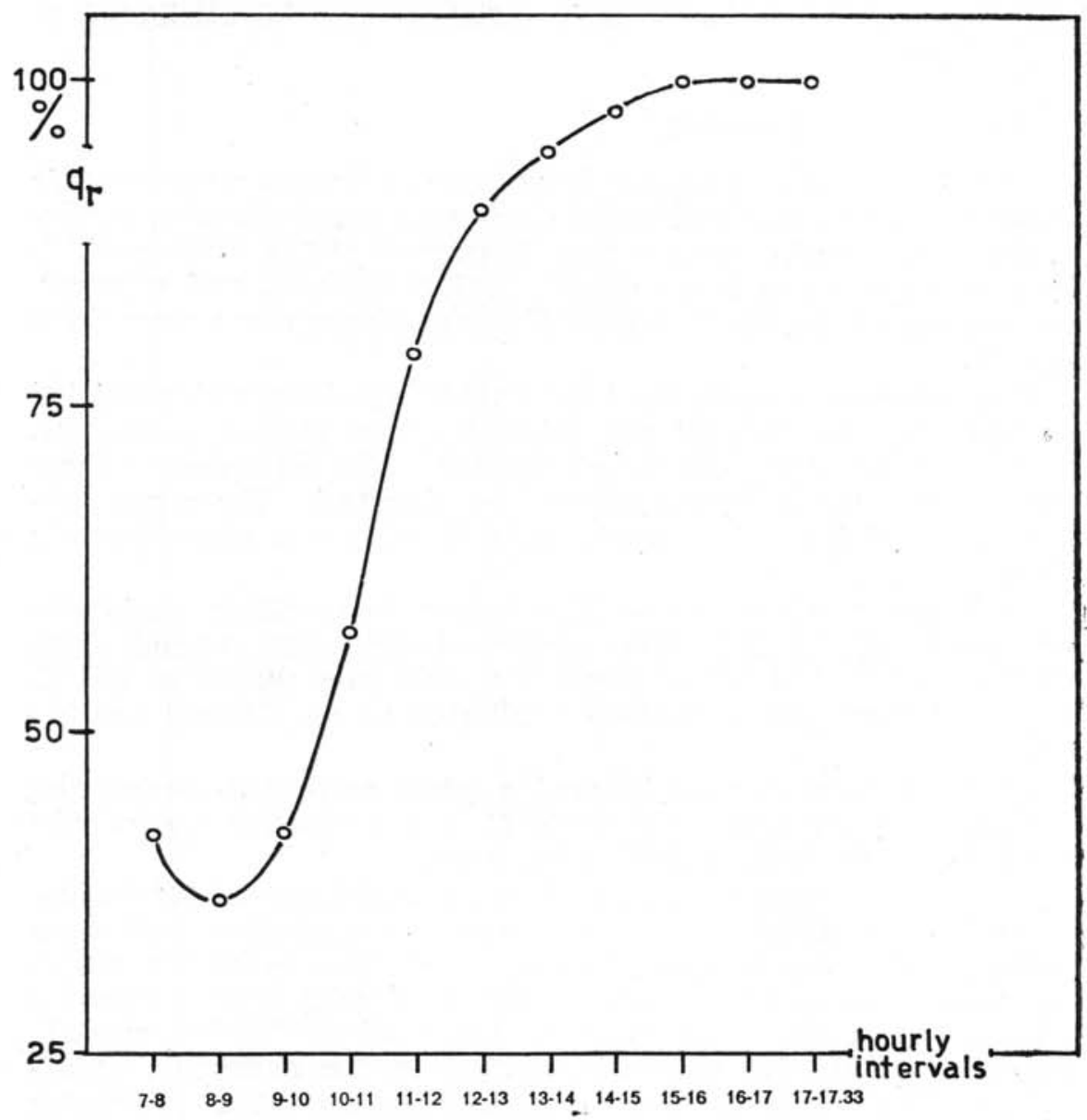

Fig. 6 - Hourly global radiation ratio $\left(q_{\mathrm{r}}\right)$ between the 7 th and the 8 th July, 1959.

$$
\begin{aligned}
q_{\mathrm{r}}=\frac{\mathrm{q}_{8}}{q_{7}} ; q_{8} & =\text { hourly global radiation on the } 8 \text { th. } \\
q_{7} & =\text { hourly global radiation on the } 7 \text { th. }
\end{aligned}
$$

- The unit of total radiant energy falling on unit area in most common use is the langley, abbreviated to ly. ( $1 \mathrm{ly}=1 \mathrm{gram}$-calorie per square centimeter). 
for the 8th: 281.00 ly.day- $^{-1}$. The incoming energy during the 2-hour intervals of exposure was calculated in order to verify any existing relationship with the organic production. The computed data are shown in the diagrams of Fig. $3 \mathrm{E}$. The mean instantaneous values of total energy flux were also computed in ly. $\mathrm{min}^{-1}$ and are shown on Fig. $8, A$ and $B$. The maximum value found on both days was 1.0 ly. min- $^{-1}$.

Hourly global radiation ratio, between the 7 th and 8 th - The morning of the 8th, was overcast with a Sc cloud layer that slowly dissipated until noon, while the morning period of the 7th was cloudless.

The ratio of the hourly incoming global radiation between the two days, was plotted on Fig. 6. By this diagram the rate of dissipation of the Sc cloud layer may be estimated in function of the time. On the 7th, during the morning (cloudless sky) the incident energy was $163.80 \mathrm{ly}$, while on the 8th (overcast sky) its value was as low as 94.20 ly $(57.5 \%)$.

A value of $208.35 \mathrm{ly}$, for the total incident energy was observed in the afternoon on the 7 th, while on the 8 th this value was of 186.80 ly (about 90\%).

Solar energy reaching the $2 \mathrm{~m}$ depth level was estimated taking into account the total incident radiation at the surface, the extinction coefficient, the radiation angle of incidence and the condition of sky and sea. The obtained data are only estimated, since the energy's extinction is a function of the wave lengths, a factor which was not observed. The calculated average percentage amount of total incident energy from sun and sky that reached the depth of $2 \mathrm{~m}$ is about $11.5 \%$, a result that confirms the classification of turbid coastal water according to Jerlov (1951, p. 50 - 52).

\section{4 - The Phytoplankton}

a) Taxonomy - From the samples collected during the two days of observations representative results were obtained on the specific nature of the constitutive elements of the phytoplankton.

The greater part of the individuals of the phytoplankton population was constituted by centric diatoms. The most frequent species among the latter were: Cerataulina bergonii H. Peragallo, Chaetoceros compressus Lauder, Melosira sulcata (Ehr.) Kut., Chaetoceros curvisetos Cleve, Stephanopyxis palmeriana (Grev.) Grunow, all of them neritic forms and a few typical of warm waters. Corethron hystrix Hensen, Hemiaulus membranaceus Cl., Rhizosolenia robusta Norman which are mainly considered to be oceanic forms (Cupp, 1943) were also present. The presence of Raphoneis crucifera (Kitton) Hagelstein, Pinnularia sp., Eunotia sp. and Terpsinoe mu- 
sica Ehr., must be mentioned as indicators of the presence of brackishwaters from the lagoon of Cananéia in the Bom Abrigo area. A few dinoflagellates were found in small numbers: Pyrocystis elegans Pavillard, Pyrocystis fusiformis (Thompson) Murray, Ceratium sp. and Peridinium sp. Cyanophyceae were scarce and only Trichodesmium erythraeum Ehr. was frequent but in small numbers.

Although brackish water indicators were found during the two days it may be ascertained that the contribution of lagoon waters species was inconspicuous in comparison with the specific composition of the phytoplankton, which remained more or less constant and steady during the observation's period.

The net phytoplankton population was constituted almost totally by diatoms, as shown on Table II.

\section{TABLE II}

GENERAL COMPOSITION OF "NET PHYTOPLANKTON" (IN PERCENT)

\begin{tabular}{|l|r|r|}
\hline \multicolumn{1}{|c|}{ Day } & 7 & 8 \\
\hline Class & & \\
\hline Bacillariophyceae & 97.5 & 98.4 \\
Dinophyceae & 2.0 & 1.5 \\
Myxophyceae & 0.5 & 0.1 \\
\hline
\end{tabular}

The genera Chaetoceros and Coscinodiscus followed by genera Corethron and Cerataulina were the most characteristic flora elements (Table III).

TABLE III

COMPOSITION OF PRINCIPAL GENERA IN THE $2 \mathrm{~m}$ WATER COLUMN

\begin{tabular}{|c|c|c|c|c|c|}
\hline \multicolumn{3}{|c|}{ day 7} & \multicolumn{3}{|c|}{ day 8} \\
\hline Genus & $\begin{array}{l}\text { number } \\
\text { of } \\
\text { species }\end{array}$ & $\%$ of ind. & Genus & $\begin{array}{c}\text { number } \\
\text { of } \\
\text { species }\end{array}$ & $\%$ of ind. \\
\hline Coscinodiscus & 5 & 49.9 & Chaetoceros & 10 & 60.8 \\
\hline Chaetoceros & 9 & 18.1 & Coscinodiscus & 4 & 16.9 \\
\hline Actinocyclus & 3 & 6.4 & Corethron & 1 & 5.6 \\
\hline Cerataulina & 1 & 6.1 & Cerataulina & 1 & 3.7 \\
\hline Corethron & 1 & 5.6 & Bacteriastrum & 3 & 2.4 \\
\hline other genera & - & 13.9 & other genera & - & 10.6 \\
\hline
\end{tabular}


b) Quantitative analysis - Table IV shows the minima and maxima as well as the arithmetical mean of all values observed for each day, at surface and at $2 \mathrm{~m}$ depth. Every isolate cell and natural colony was taken into account. It must be noted that no correlation was found between the tidal currents and the existing variations in individual concentration of population (Table IV).

TABLE IV

POPULATIONS INDIVIDUAL CONCENTRATION (NUMBER OF CELS PER LITRE)

\begin{tabular}{|l|r|r|r|r|}
\hline & \multicolumn{2}{|c|}{ day 7 } & \multicolumn{2}{c|}{ day 8 } \\
\hline depth & & & & \\
main values & $0.0 \mathrm{~m}$ & $2.0 \mathrm{~m}$ & $0.0 \mathrm{~m}$ & $2.0 \mathrm{~m}$ \\
\hline minima & & & & \\
\hline mean & 115,341 & 98,452 & 145,515 & 119,770 \\
\hline maxima & 185,616 & 175,677 & 198,986 & 164,382 \\
\hline
\end{tabular}

c) The physiological conditions of the phytoplankton population were estimated through the cells apparent state, pigment analysis and the ratio "net community production" to "gross production". The cell's physiological conditions was judged mainly from the frustules' position and structural state of the chromatophores. The following data concerning cells in poor conditions were obtained from the analysis (Table V).

TABLE V

CELLS IN POOR CONDITIONS (\%)

\begin{tabular}{|l|c|c|}
\hline & 7 & 8 \\
main values & & \\
\hline minima & 8.0 & 5.0 \\
\hline mean & 11.0 & 9.0 \\
\hline maxima & 23.0 & 15.0 \\
\hline $\begin{array}{l}\text { total number of } \\
\text { cells examined }\end{array}$ & 722,548 & 717,908 \\
\hline
\end{tabular}

The pigment analysis reveals more abundant chlorophyll per cell number indicating a better physiological condition on the 8th. However, one of the best methods for the evaluation of the plankton's physiological behavior is the ratio: net photosynthesis 
to gross photosynthesis in an optimum intensity of light energy. In a healthy population this ratio should be approximately $0.90-0.95$, if respiration is 5 to $10 \%$ of total photosynthesis (Ketchum et al., 1958) .

The following ratios were obtained: 0.54 and 0.56 on the 7 th; 0.61 and 0.67 on the 8th (Fig. 5).

Taking into account that the values obtained were originated from the ratio net community production to gross production, and without considering it only for the light optimum, but including all intensities, limiting and inhibiting as well, it is expected the values ubtained will suffer an increase. The methods used suggest that the population was reasonably healthy.

\section{IV - SOLAR RADIATION AND ORGANIC PRODUCTION}

Many authors have studied the effects of solar radiation energy on organic production. The intention of this part of the work is to give the preliminary results of the relation between solar radiation and the organic production at the surface layer under natural conditions in coastal waters of the region of Cananéia.

The environment analysis enable us to suppose that hydrological conditions remained fairly constant throughout the period of observations and that nutrients - particularly nitrate and phosphate were found in sufficient amounts.

Hence, solar radiation may under the existent conditions be considered as the most important controlling factor of organic production.

The different groups of planktonic algae respond in a very different way to light of different wave lenghts. The spectral distribution and solar radiation intensity change, in turbid waters, considerably with depth and an estimate of the quality and quantity of the energy with depth is very difficult to establish without direct measurements. For these reasons the relationship between solar radiation and organic production was studied only at the surface.

\section{1 - RELATIONSHIP BETWEEN TOTAL INCIDENT RADIATION AND ORGANIC PRODUCTION}

An attempt was made to study the relationship between the organic production and the total incident solar radiation taking into consideration a mixed natural population living at the surface of turbid coastal waters. The phytoplankton population was constituted almost totally of diatoms (98\% - see Table II). Taking into account the different concentration of the phytoplankton stan- 
ding crop a correction of the gross production figures is necessary in order to obtain the effect which would be expected by phytoplanktonic population of homogeneous density. This correction was applied by calculating the gross production in terms of one unit of pigment.

The resulting data were plotted on Figure 7 which shows the gross production per unit of pigment against global radiation per two hours.

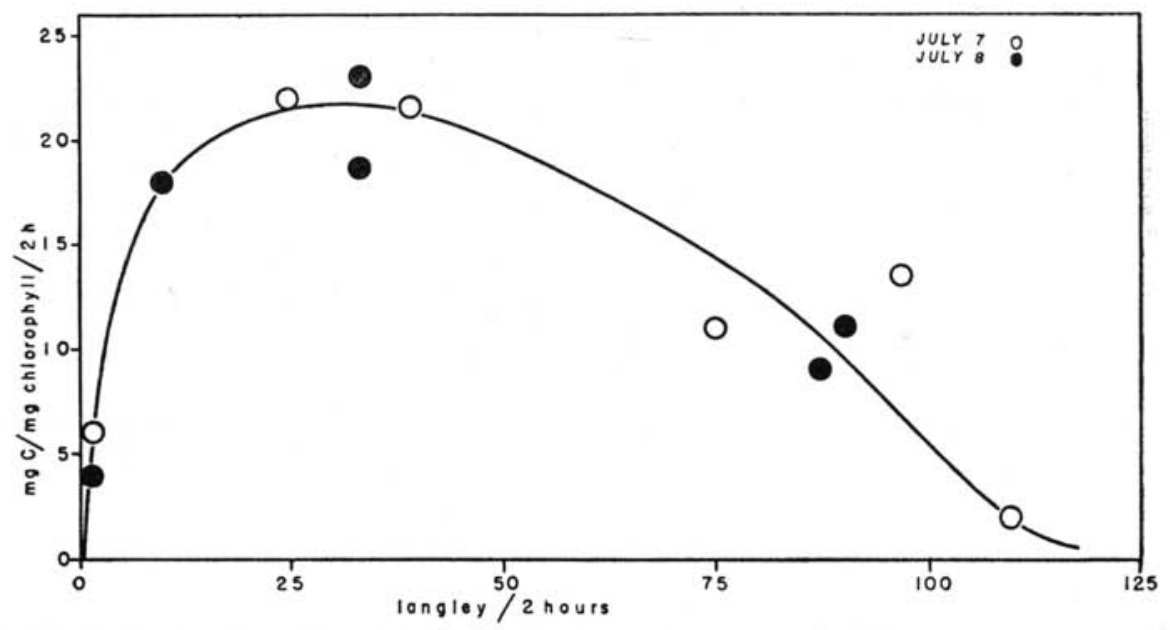

Fig. 7 - Relationship between total incident solar radiation energy and gross production per unit of chlorophyll, for the exposure intervals (2 hours).

The percentual reflected intensities of global radiation were also computed at the surface as a function of the solar altitude and sea and sky conditions (Sverdrup, 1952). Through the plotted points a smooth curve was drawn. The curve shows that the total incident radiation saturation intensity lies between 25 and 40 ly per two hours. The correspondent mean instantaneous total incident radiation intensity varies between 0.21 and $0.33 \mathrm{ly} . \mathrm{min}^{-1}$. The mean gross production per unit of pigment corresponding to the global radiation saturation intensity is approximately $22 \mathrm{mg} \mathrm{C} / \mathrm{mg}$ chlorophyll/2 hours.

\section{2 - RELATIONSHIP BETWEEN THE DIURNAL VARIATION OF ORGANIC PRODUCTION AND GLOBAL RADIATION}

Since the hydrological conditions may be considered having small dailly variations, the most important controlling factor of 
daily organic production seems to be the diurnal variation of solar radiation intensity.

The diurnal variation of global radiation, in ly. $\mathrm{min}^{-1}$, and the relative organic production were plotted on Fig. 8.

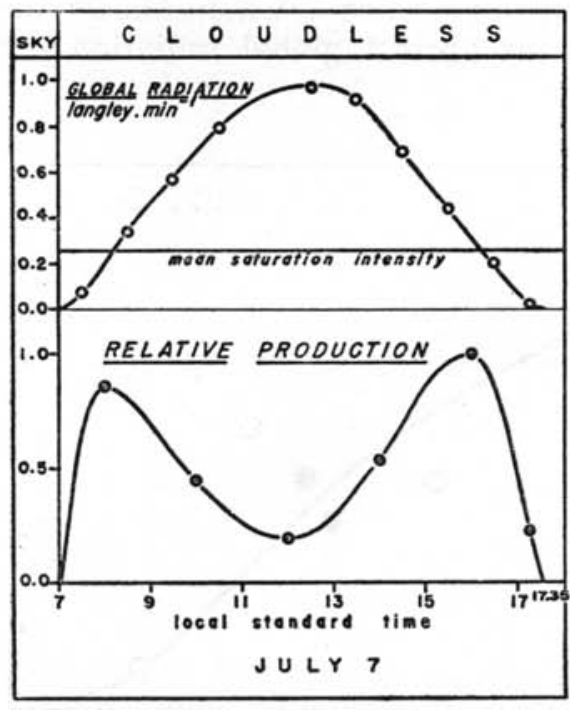

A

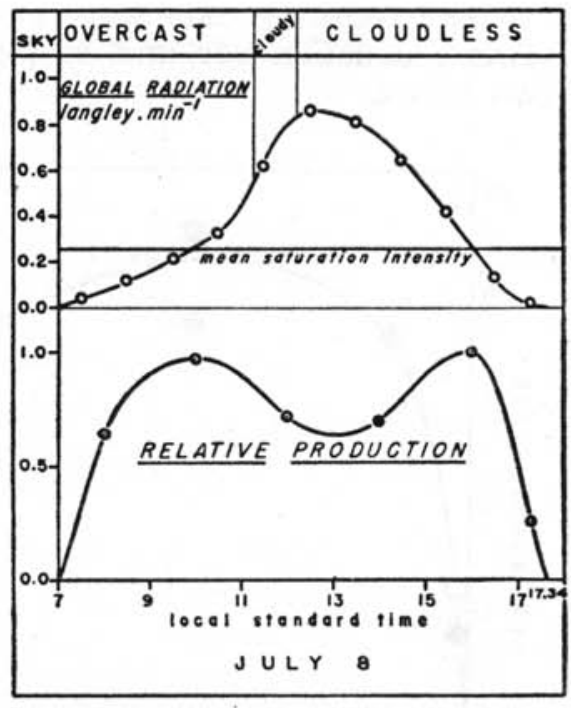

B

Fig. 8 - Diurnal variation of total incident energy and relative production.

An increase of the organic production may be observed with the global radiation up to a saturation point corresponding to a mean instantaneous intensity which lies between 0.21 and $0.33 \mathrm{ly} \cdot \mathrm{min}^{-1}$. For higher intensities the gross production diminishes gradually with the corresponding increase of total incident solar radiation intensities in consequence of the inhibitive effect on the phytoplankton photosynthesis.

On the morning of July 8th the sky remained overcast until 1120 A. M., cloudy until 1215 P. M. and cloudless until sunset. On the other hand, July 7th was a completely cloudless day. It is interesting to note a greater organic production during the overcast period in comparison with the corresponding cloudless one. This may be attributed to the attenuation of the solar radiation intensity, with a consequent attenuation of the inhibitory effect. The total incident solar radiation attenuation was decreasing in consequence of the dissipation of the cloud layer as is shown on Figure 6 .

The mean instantaneous global radiation saturation intensity of $0.27 \mathrm{ly}$. min- ${ }^{-1}$ was drawn on Figure 8 , therefore these experiments 
shows that even during winter (sun's altitude at noon $42^{\circ}$, length of the day about 10.6 hours) in the greater part of bright sunny days the solar radiation intensities at surface is higher thar the sacuration intensity.

For the same hydrological conditions, in overcast days, organic production at the surface may be expected to be higher than in cloudless days, by the attenuation of the inhibitory effect due to super-saturation radiation intensities. The mean instantaneous total incident radiant energy saturation intensity is about $30 \%$ of the maximum (1.0 ly. $\left.\min ^{-1}\right)$.

About $90 \%$ of the lenght of the diurnal period of the bright sunny day the inhibition of photosynthesis became apparent at surface level. In overcast days this relation may be expected to be much smaller.

The present results agree closely to the results and graphs of Ryther (1956, p. 61-70).

\section{3 - Light INTENSITY AND RELATIVE PRODUCTION}

Most authors study the relations between organic production and light energy, considered as the part of the spectrum photosynthetically active.

The mean instantaneous total solar and sky radiation in ly. min-1 was converted to illumination units, in foot-candles according to Kimball (1924) as a function of the sun's zenith distances, and the correspondent sky conditions.

On Figure 9 the computed mean light intensity was plotted against relative production, and a smooth curve was drawn graphically through the plotted points.

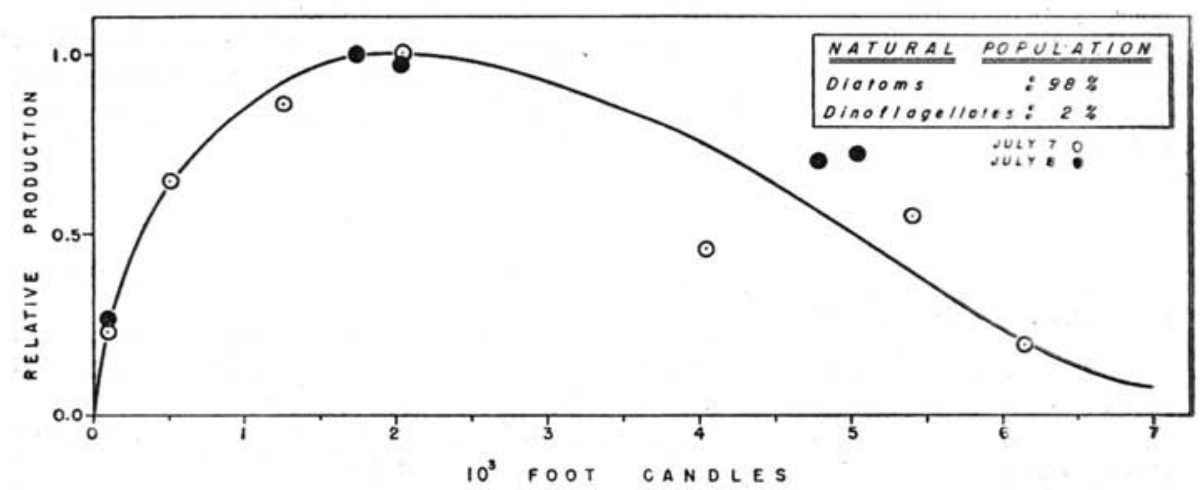

Fig. 9 - Relationship between relative production and light intensity at Bom Abrigo Island natural population. 
The curve shows that the light saturation intensity lies between 1,700 and 2,200 ft.cdl, for the natural population living in the turbid coastal waters of Bom Abrigo Island. This results fit quite well with those presented by Ryther (1956, p. 61-70), Steemann Nielsen \& Hansen (1959a).

\section{$\mathrm{V}-$ CONCLUSIONS}

The natural phytoplankton population living in the coastal waters of Bom Abrigo Island consisted mainly of diatoms, and was found to be in good physiological conditions in winter 1959.

The nutrient $\left(\mathrm{PO}_{4}\right)$ content was present in sufficient amount.

The maximum rate of organic production was about $93.00 \mathrm{mgC}$ $/ \mathrm{m}^{3} / 2 \mathrm{~h}$ at the surface and $131.25 \mathrm{mg} \mathrm{C} / \mathrm{m}^{3} / 2 \mathrm{~h}$ at $2.0 \mathrm{~m}$ depth.

The organic production diurnal variation is controlled mainly by the diurnal variation of the solar radiation intensity.

The mean instantaneous total radiation saturation intensity was observed to be about $0.27 \mathrm{ly}$. min-1 and the correspondent light saturation intensity lies between 1,700 and 2,200 ft. cdl.

The mean rate of light satured organic production was about $22 \mathrm{mgC} / \mathrm{mg}$ Chlorophyll /2 hours.

These results seem to be those expected from typical sun plankton, living in tropical seas in surface layers (according to Steemann Nielsen \& Hansen, 1959a).

\section{VI-A C K N O L E D G E M N T S}

The spectrophotometric measurements for the determination of pigment contents was available to the authors by kindness of Miss Olga Young Castellani, physicist of the Histology Department of the Faculty of Medicine of the University of S. Paulo. The drawings and graphs were made by Mr. I. Marcondes, technical assistant. In the field work the authors were helped by Mr. C. de Jesus and Mr. C. C. Sarti, technical assistants. The authors wish to thank Dr. M. Vannucci and Mr. E. Ramos for the help given in making the English text more idiomatic.

\section{VII - S U M Á R I O}

O presente trabalho é uma primeira estimativa da produtividade primária na região de Cananéia.

Tem por principal objetivo obter resultados preliminares sôbre as variações diurnas da produção da população natural que vive nas águas costeiras, em função dos fatổres ambientais.

Com esta finalidade a maioria dos fatôres que intervêm na produtividade primária foram medidos e observados durante 2 dias, no período diurno em intervalo de 2 em 2 horas. foram:

Os principais fatôres considerados na avaliação da produção primária 
a - "Taxa de produção bruta" (gross production rate) dos organismos marinhos.

b - Ambientes físico e químico.

c - Relação entre a energia total incidente e a produção orgânica.

O equipamento, os métodos e procedimentos empregados na obtenção dos resultados são apresentados.

A produção orgânica foi determinada pela técnica do oxigênio de Gaarden \& Gran (1927), a concentração de oxigênio foi medida pelo método de Winkler.

O método empregado na dosagem da concentração de pigmentos foi o de Richards com Thompson (1952), Creitz \& Richards (1955), Davis (1957) e o cômputo efetuado por meio das equações de Richards com Thompson.

Os coeficientes de extinção foram obtidos pela observação do disco de Secchi e computados pela expressão de Poole \& Atkins.

A análise quantitativa do fitoplâncton foi efetuada pelo método de filtração "filtro milipóro" (millipore filter) e contagem microscópica de acôrdo com o "método de contagem de grupos" (clump count method).

Os demais fatôres foram obtidos através de medidas diretas ou por métodos usuais.

A análise dos resultados e das observações permite as seguintes conclusões:

A população fitoplanctônica natural que vive nas águas túrbidas costeiras da Ilha de Bom Abrigo foi encontrada em boas condiçốes fisiológicas e é constituída principalmente por diatomáceas.

Os sais nutrientes (fosfatos) são encontrados em quantidades suficientes.

A taxa máxima de produção orgânica é aproximadamente $93 \mathrm{mg} \mathrm{C} / \mathrm{m}^{3} / 2 \mathrm{~h}$ na superfície de $131,25 \mathrm{mg} \mathrm{C} / \mathrm{m}^{3} / 2 \mathrm{~h}$ a $2,0 \mathrm{~m}$ de profundidade.

A variação diurna da produção orgânica mostrou ser controlada principalmente pela variação diurna da intensidade de radiação solar global.

A intensidade instantânea média saturante da radiação global é de 0.27 ly. $\min ^{-1} \mathrm{e}$ a intensidade de iluminamento saturante varia entre 1.700 e 2.200 lumen . pé-2.

A taxa média da produção orgânica para a energia saturante é aproximadamente de $22 \mathrm{mg} \mathrm{C/mg} \mathrm{de} \mathrm{clorofila} \mathrm{/} 2$ horas.

Os resultados obtidos mostram ser compatíveis com os esperados para o "plâncton de sol" (sun plankton), que vive nas águas superficiais dos mares tropicais (Steemann Nielsen \& Hansen, 1959).

\section{VIII - R E F E R E N C E S}

BRAARUD, T.

1958. Counting methods for determination of the standing crop of phytoplankton. Cons. Perm. Int. Expl. Mer, Rapp. Proc. Verb. Reun., vol. 144, p. 17-19.

Crettz, G. I. \& Richards, F. A.

1955. The estimation and characterization of plankton populations by pigment analyses. III. A note on the use of "millipore" membrane filters in the estimation of plankton pigments. Jour. Mar. Res., vol. 14, p. 3-211.

Cupp, E. E.

1943. Marine plankton diatoms of the West Coast of North America. Bull. Scripps Inst. Ocean. Univ. California, vol. 5, n. 1, p. 1-238, est. 1-5, 168 figs. 
JERLOV, N. G.

1951. Optical studies of ocean waters. Rep. Swedish Deep-Sea Exp. 1947-1948, vol. III, fasc. I, p.1-69.

Kato, $\mathrm{K}$.

196?. Chemical investigation on the hydrographical system of Cananéia Lagoon. 1. General feature of regional distribution of chemical constituents in the water of Cananéia Lagoon. Bol. Inst. Ocean. (under press).

Ketchum, B. H. et al.

1958. Productivity in relation to nutrients. Cons. Perm. Int. Expl. Mer, Rapp. Proc. - Verb. Reun., vol. 144, p. 132-140.

KREY, J.

1958. Chemical methods of estimating standing crop of phytoplankton. Cons. Perm. Int. Expl. Mer, Rapp. Proc. - Verb. Reun., vol. 144 , p. $20-27$.

MURPhy, J. \& RILEY, J. P.

1956. Storage of sea-water samples for the determination of dissolved inorganic phosphate. Anal. Chim. Acta, vol. 14, p. 318-319.

REDFielid, A. C.

1958. The biological control of chemical factors in the environment. Coll. Reprints Woods Hole Ocean. Inst., Contr. n. 976, p. 205-22.

RICHARDS, F. A.

1952. The estimation and characterization of plankton population by pigment analyses. I. The absorption spectra of some pigments occurring in diatoms, dinoflagellates and brown algae. Jour. Mar. Res., vol. XI, n. ${ }^{\circ} 2$, p. 147-155.

Richards, F. A. with Thompson, T. G.

1952. The estimation and... II. A spectrophometric method for the estimation of plankton pigments. Jour. Mar. Res., vol. XI, n. ${ }^{\circ}$ 2, p. $156-172$.

Richardson, I. D. \& Moraes, M. N. de

1960. A first appraisal of the landing and mechanism of the Santos fishery. Bol. Inst. Ocean., vol. XI, fasc. 1, p. 5-85.

RILEy, G. A. \& SchurR, H. M.

1959. Transparency of Long Island Sound-Waters. Bull. Bingham Ocean. Coll., vol. 17, p. 66-82.

RYTHER, J. H.

1956. Photosynthesis in the ocean as a function of light intensity. Coll. Reprints Woods Hole Ocean. Inst., Contr. n. 819, p. 61-70. July 1957.

Steemann Nielsen, E. \& Hansen, V. K.

1959. Measurements with the carbon-14 technique of the respiration rates in natural populations of phytoplankton. Deep-Sea Res., vol. 5, n. ${ }^{\circ} 3$, p. $223-233$.

1959a. Light adaption in marine phytoplankton and its interrelation with temperature. Physiol. Plant., vol. 12, p. 353-370. 
StrickLand, J. D. H.

1958. Solar radiation penetrating the ocean. Jour. Fish Res. Board Canada, vol. 15 , n. ${ }^{\circ} 3$, p. $453-493$.

1959. The primary productivity and fertility of the northeast Pacific and the British Columbia coastal waters. Progr. Rep. Pacific Coast Stat., n. ${ }^{\circ} 113$, p. 13-15.

SVERDRUP, H. U.

1952. Oceanography for meteorologist. London, George Allen \& Unwin Ltd., p. 53-56.

SVERdRUP, H. U., Johnson, M. W. \& Fleming, R. H.

1946. The Oceans. New York, Prentice-Hall, p. 235-239. 